\title{
frontiers
}

FOR YOUNG MINDS

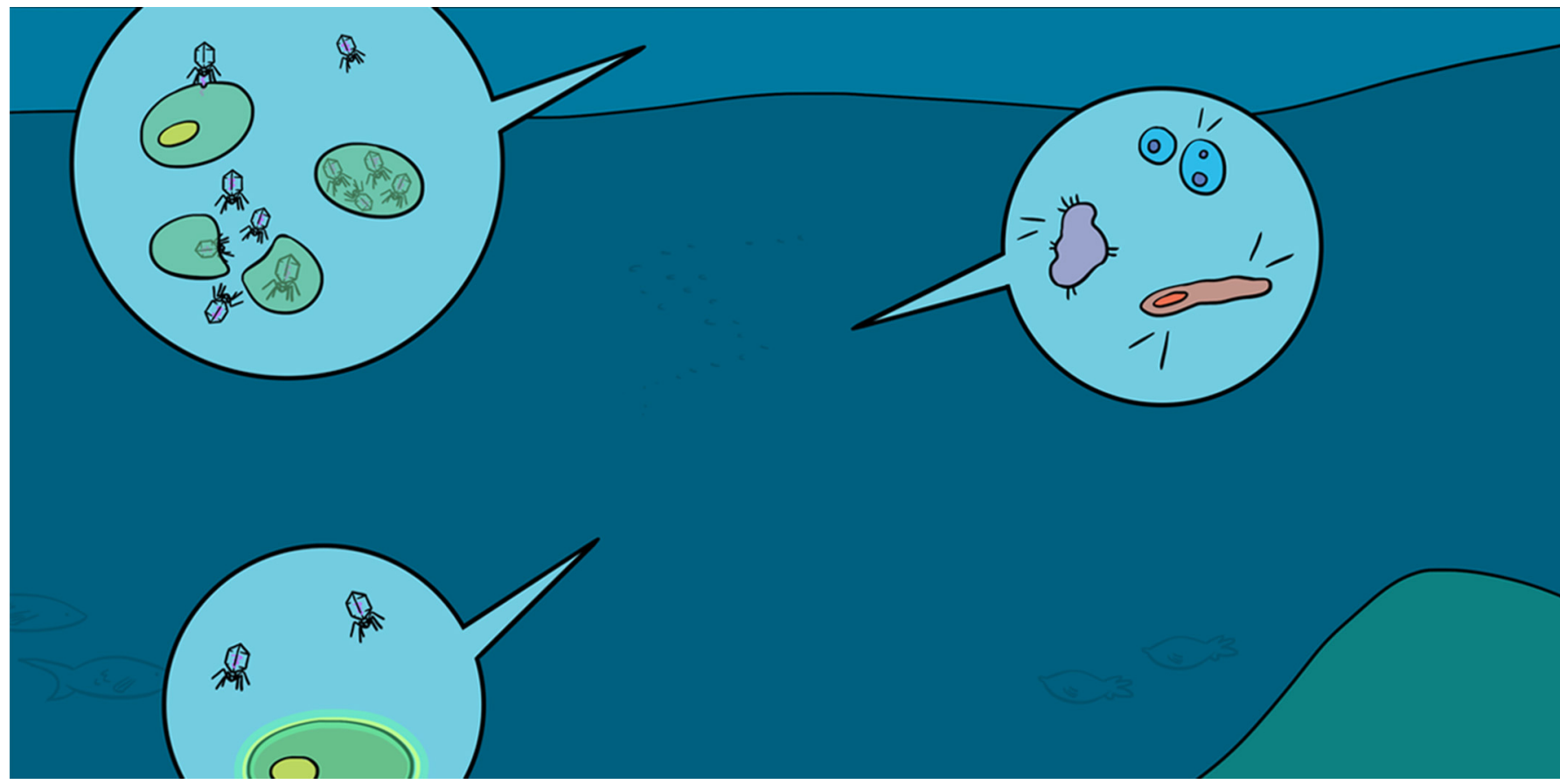

\section{VIRUSES-AGENTS OF CHANGE IN THE OCEANS}

\section{Sarit Avrani ${ }^{1,2^{*}}$ and Daniel Sher ${ }^{3 *}$ \\ ${ }^{1}$ The Department of Evolutionary and Environmental Biology, University of Haifa, Haifa, Israel \\ ${ }^{2}$ The Institute of Evolution, University of Haifa, Haifa, Israel \\ ${ }^{3}$ The Department of Marine Biology, Leon H. Charney School of Marine Sciences, University of Haifa, Haifa, Israel}

YOUNG REVIEWER:

SHASHIPREE-

THAM

AGE: 14
Viruses are usually thought of as the cause of countless diseases. However, in the oceans, viruses are part of the natural cycle of life and death. This article discusses marine viruses that infect phytoplankton-the tiny micro-algae that form the base of the marine food web and affect Earth's climate. Through an ongoing "arms race" between viruses and the cells they infect, viruses can promote the evolution of their hosts, and even help their hosts acquire genes that can help them survive. By killing phytoplankton species that become very abundant, viruses can allow other species to grow, promoting biodiversity. Finally, viruses affect global cycles of carbon and other elements, indirectly influencing the climate of our planet.

\section{VIRUSES ARE EVERYWHERE, EVEN IN THE OCEANS}

Everyone has heard of viruses. They cause diseases, such as the flu, Ebola, Smallpox, and of course the COVID-19 respiratory disease. 


\section{HOST}

Organism in which a virus can reproduce. Each virus reproduces in only one or a few related hosts. The host must have the right receptors that the virus can identify.

\section{PHYTOPLANKTON}

Microscopic organisms that obtain their energy from the sun by photosynthesis. They are an important component of all aquatic food webs.

\section{Figure 1}

Example structures of two marine viruses and a summary of the viral life cycle.
What is less often known is that viruses do not only cause diseases in humans - they are found everywhere and infect essentially every known form of life. More importantly, viruses affect not only the health of the organisms they infect but also entire ecosystems. In fact, viruses are an important contributor to the cycling of elements, such as carbon, nitrogen, and phosphorus. Viruses are also agents of change and renewal, affecting the genetics and evolution of their host organisms, and increasing the biodiversity of the ecosystems in which they are found.

We know a lot about the ecology of viruses found in the ocean. Over the past 20 years or so, we have learned much about the viruses that infect single-celled micro-algae called phytoplankton, which dwell in the upper $200 \mathrm{~m}$ of the oceans where sunlight can penetrate. Phytoplankton are known as the "plants of the sea"-they are responsible for about half of the photosynthesis on Earth and they provide the food for many other marine organisms, from bacteria to whales. Because of the ecological importance of phytoplankton, the viruses that infect them have been studied in detail (Figure 1) $[1,2]$.

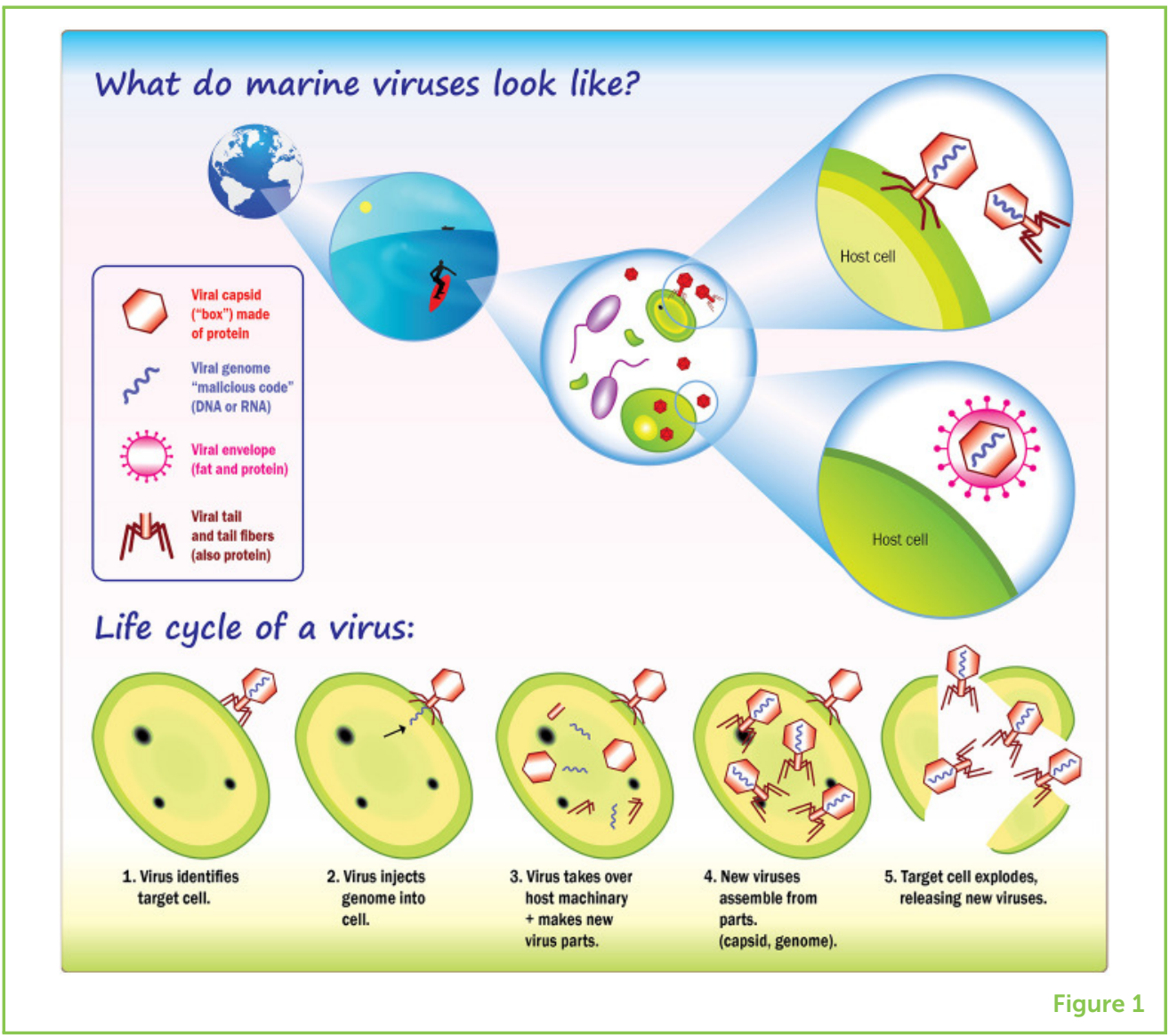




\section{CAPSID}

A protein shell that protects the genomic material of the virus, during its search for a new host to infect.

\section{GENOME}

The complete set of instructions needed to build and maintain an organism. Each set of instructions is stored in a gene. The viral genome is made of DNA or RNA.

\section{RECEPTORS}

Various molecules on the surface of cells that may be used as recognition signals by viruses. Each virus identifies specific receptor/s on the surface of its host.

\section{WHAT IS A VIRUS?}

Viruses can be thought of as biological nano-machines with one goal in life-to replicate. All viruses are built of an external "box" made of proteins, called a capsid, which protects the DNA or RNA that forms the genome of the virus. The capsid is sometimes surrounded by a second envelope that also includes fat molecules. This is why washing your hands with soap destroys some viruses including the SARS-CoV-2 virus-it dissolves the fat layer. Viruses do not infect every cell they meet-they have to encounter the appropriate host, recognizing it using specific molecules on the host cell surface called receptors. When the virus encounters its host, it either enters the cell or injects its genome inside. The virus is now only an empty shell, but its genome is like a malicious code that takes over the host cell and forces it to become a factory for producing new viruses. Once the new viruses are assembled inside the host, and ready to infect new cells, they are released while the host cell often explodes and dies.

Many viruses are quite simple, with a malicious code that includes very few "commands" (genes in the genome). Some of these commands shut down the natural processes inside the cell, whereas other commands instruct the cell to produce the building blocks that assemble into new viruses - the viral genome, the proteins that build the capsid, and sometimes the fat layer. However, scientists have found that some viruses are much more complex. Some marine viruses have genes that allow them to modify cellular processes, such as photosynthesis, the production of specific cell components, or the ways that cells sense their environment [1]. This has led to the hypothesis that many viruses do not just shut down their target cells. The virus malicious code takes over the command center of an infected cell, changes the way the cellular machinery works, and transforms the host cell into a virus-cell hybrid called a virocell. The virocell is programmed to stay alive just long enough to produce as many viruses as possible [2].

\section{AN "ARMS RACE" BETWEEN VIRUSES AND CELLS}

Viruses can be fearsome parasites-taking over the host cell and making it a "zombie" virocell. The host cells, however, do not just sit by-they fight back (Figure 2). For example, some cells produce tiny cell-like structures that may be decoys for viruses. So, instead of infecting the real cell, the viruses attack the decoys. Another common way for host cells to avoid virus attack is using camouflage. Host cells may change the receptors on their surfaces such that the virus can no longer recognize the cell as a potential host [3].

Bacteria can also try and protect themselves after the virus has injected its malicious code, preventing the production of new viruses. For example, bacteria may break up the viral genome into small pieces, 
Figure 2

Viruses and their host cells are continually changing and adapting to find ways to counter each other's defenses to better survive (this is called an "arms race"). The top row shows cells that are sensitive to viruses and the bottom shows several defense mechanisms that cells use to protect themselves against viruses.

\section{ARMS RACE}

An ongoing cycle in which a predator develops an advantage over its prey, followed by the prey then developing its own advantage, and so on.

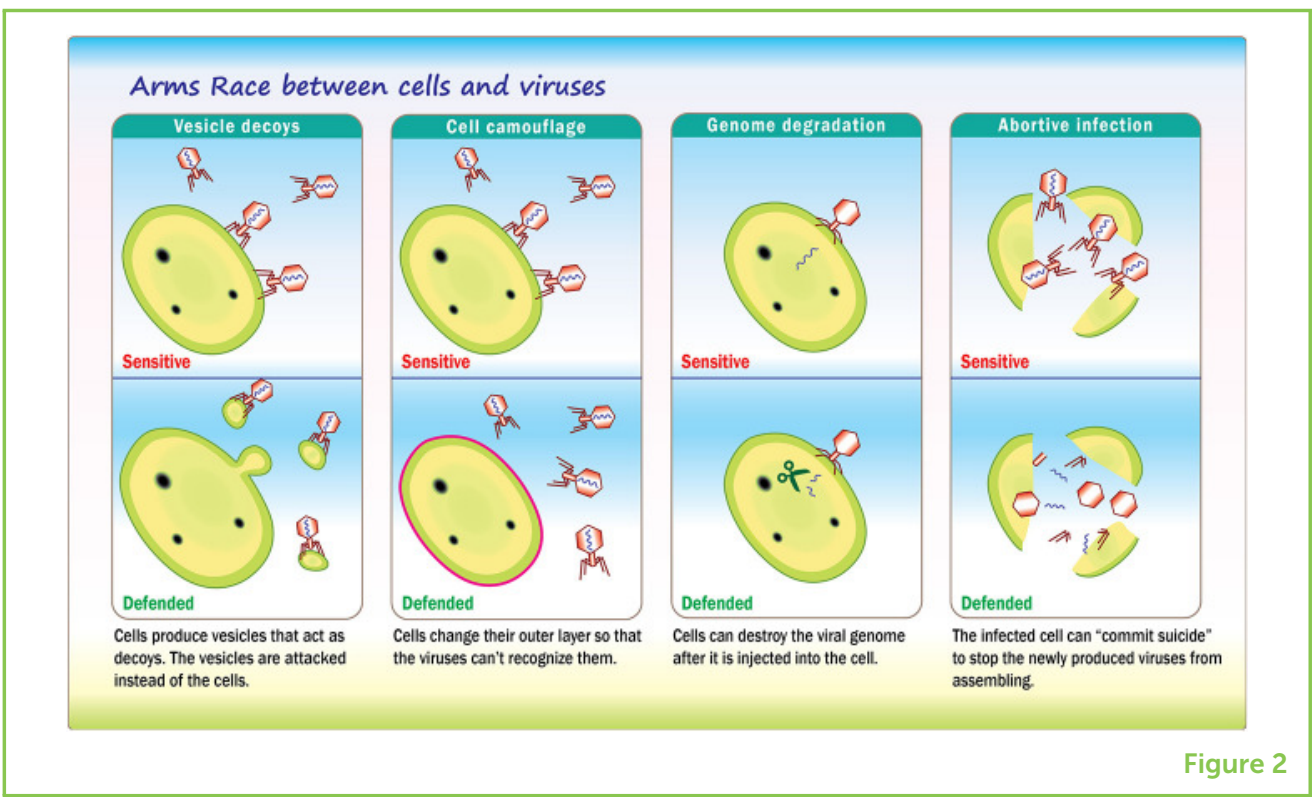

thus stopping the virus from taking over the cell. Finally, some cells "commit suicide" when they realize they are being taken over by viruses. If the cell dies quickly enough, the new viruses may not have time to assemble and be ready to infect new cells.

Since this is an arms race, the viruses also evolve ways to counter the cells' defenses. When the host cell changes its appearance, viruses can evolve to recognize new receptors on the disguised host. The virus can sometimes even evolve to recognize new hosts that it could not recognize previously. This is what probably happened with the SARS-CoV-2 virus that causes COVID-19. In this case, a virus that used to infect bats or pangolins gained the ability to infect humans. Also, viruses can sometimes evade the immune system of the host, for example by producing proteins that interfere with the cell's defense mechanisms. To survive, the host will have to change as well, to ensure its immune system can recognize the virus and stop it. This arms race between viruses and host cells is ongoing, with each side adapting and changing in response to the strategies of its opponent.

\section{VIRUSES AS AGENTS OF CHANGE AND DIVERSITY}

The ongoing arms race between viruses and their host cells may seem like a destructive process, but like other examples in nature, a destructive process can bring about new life. Just as a wildfire that burns a forest can allow new and potentially different trees to grow, a virus that infects and kills a population of bacteria or phytoplankton can enable other organisms to grow instead. In this process, viruses often infect the most abundant and successful organisms, because high abundance means it is easier to find host cells to infect. When an extremely abundant host is killed by viruses, the rarer organisms 


\section{FOOD WEB}

A network of organisms that eat one another, so that energy and elements flow along the web, from prey to predators.

\section{ZOOPLANKTON}

Very small organisms that live in aquatic habitats. They feed on phytoplankton, bacteria, or other zooplankton. Micro-zooplankton are built of one cell. Larger zooplankton can reach a few millimeters. now have enough space and food to grow, with the result being an increase in biodiversity.

Viruses have another way of increasing diversity-they cause the exchange of genes between organisms. As viruses assemble inside a host cell, they sometimes pack a piece of host DNA into their capsids by mistake. When these faulty viruses infect a new cell they cannot kill it, because they do not have their entire malicious code to inject. Instead, they inject the DNA from their previous host, which can be incorporated into the new cell's code. This can lead to genetic change in the host. In fact, about $8 \%$ of our own human DNA is made of ancient pieces of DNA that came from ancient viruses (termed fossil viruses). These fossil viruses are involved in important processes in our bodies [4].

\section{MARINE VIRUSES, FOOD WEBS AND ELEMENT CYCLING}

Viruses may be tiny-more than 1,000 times smaller than the width of a human hair-yet when they infect phytoplankton cells, viruses can impact the entire marine food web, as well as the cycling of elements, such as carbon, nitrogen, and phosphorus (Figure 3). When phytoplankton perform photosynthesis, they harness the energy of the sun to turn carbon dioxide $\left(\mathrm{CO}_{2}\right)$ and water into sugar and oxygen. This process produces oxygen and removes $\mathrm{CO}_{2}$ from the atmosphere. Oxygen is essential for most living creatures and $\mathrm{CO}_{2}$ is a greenhouse gas. The sugar produced by photosynthesis, which is partly made from the $\mathrm{CO}_{2}$ taken up by phytoplankton, is used to make other biological molecules, such as proteins. These proteins then serve as food for the entire marine ecosystem, including fish, zooplankton, whales, and humans. In this way, the carbon from the atmosphere becomes part of the food web (Figure 3). When viruses kill their phytoplankton hosts, they may disrupt this process, by releasing the photosynthetic products to the surrounding waters. This release prevents the consumption of phytoplankton by larger animals, and can potentially reduce the amount of carbon that moves up the food web. Each day, an estimated $10^{28}$ viral infections occur in the world's oceans ( 1 followed by 28 zeros, or 10 octillion) [2]. These infections release up to one billion tons of carbon from cells daily. Although each phytoplankton cell is tiny, the influence they have on our planet is massive.

Sometimes when viruses kill their phytoplankton hosts, they can increase the growth of other phytoplankton and bacteria. This is because when the virus-infected cell "explodes," it can release elements, such as nitrogen and phosphorus, which are then available for other phytoplankton and bacteria to recycle and use for their growth. 
Figure 3

Viruses affect the marine carbon cycle.

Through

photosynthesis,

phytoplankton turn

carbon into the

molecules that build

living cells.

Phytoplankton are

eaten by larger

organisms, such as

micro-zooplankton,

which are then eaten

by larger zooplankton,

and other animals, such

as fish. This transfers

the carbon up the food

web. When larger

animals breathe, they

release some of the

carbon back into the

atmosphere as $\mathrm{CO}_{2}$,

and when they die their

bodies sink to the

ocean floor and are

degraded by marine

bacteria. In contrast,

virus-infected

phytoplankton die

before they can be

eaten, and their carbon

is rapidly recycled by

bacteria.

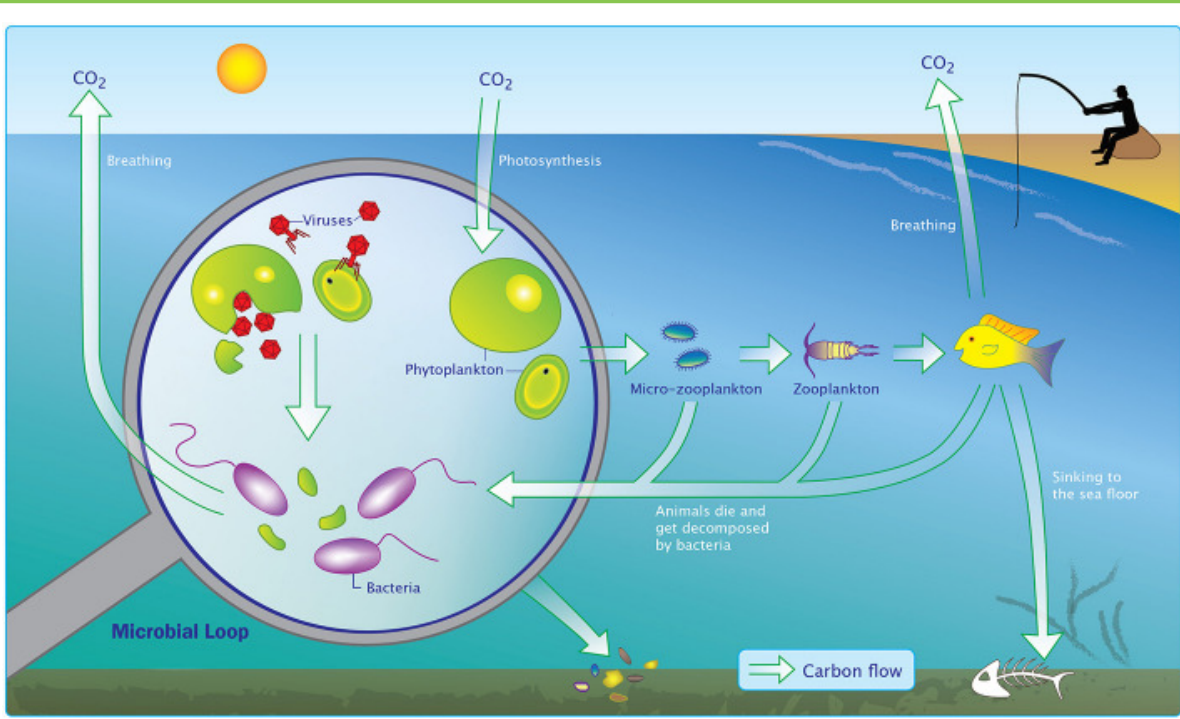

Figure 3

Finally, when phytoplankton, bacteria, and animals die in the oceans, some of the material that makes up their bodies sinks to the ocean floor. This includes the $\mathrm{CO}_{2}$ that was originally taken up by phytoplankton, effectively removing this greenhouse gas from the atmosphere and reducing global warming. When viruses kill phytoplankton, the phytoplankton cells are broken to tiny pieces that rarely sink, and are not available for larger animals consumption. Therefore, marine viruses probably reduce the amount of $\mathrm{CO}_{2}$ transported to the bottom of the oceans, thus impacting not only the lives of the cells they infect but also the entire marine food web and even, potentially, the climate of our planet $[2,5]$.

\section{AN ARMS RACE IN A DROP OF WATER}

The next time you go to the sea-shore (or to any lake, stream, or spring), remember that every drop of water is teeming with microscopic life, such as phytoplankton and bacteria, as well as their viruses. Within each drop of water, there is an ongoing arms race between the viruses and their hosts, that brings with it death but also growth and diversity. Indeed, marine viruses are part of the natural cycle of life and death in the ocean. In that way, the tiny marine viruses can be major players in the health of our planet.

\section{ACKNOWLEDGMENTS}

We thank Sari Eran Herskovitz for her patience and talent in drawing these illustrations. We thank Einav and Idan Garten, Alon and Maayan Sher, Ari Harris, and Gaia Segrè for many excellent suggestions. 


\section{REFERENCES}

1. Breitbart, M. 2012. Marine viruses: truth or dare. Annu. Rev. Mar. Sci. 4:425-48. doi: 10.1146/annurev-marine-120709-142805

2. Breitbart, M., Bonnain, C., Malki, K., and Sawaya, N. A. 2018. Phage puppet masters of the marine microbial realm. Nat. Microbiol. 3:754-66. doi: 10.1038/s41564-018-0166-y

3. Labrie, S. J., Samson, J. E., and Moineau, S. 2010. Bacteriophage resistance mechanisms. Nat. Rev. Microbiol. 8:317-27. doi: 10.1038/nrmicro2315

4. Chuong, E. B. 2018. The placenta goes viral: retroviruses control gene expression in pregnancy. PLOS Biol. 16:e3000028. doi: 10.1371/journal.pbio.3000028

5. Suttle, C. A. 2007. Marine viruses-major players in the global ecosystem. Nat. Rev. Microbiol. 5:801-12. doi: 10.1038/nrmicro1750

SUBMITTED: 03 June 2020; ACCEPTED: 18 May 2021;

PUBLISHED ONLINE: 17 June 2021.

EDITED BY: Sanae Chiba, Japan Agency for Marine-Earth Science and Technology (JAMSTEC), Japan

CITATION: Avrani S and Sher D (2021) Viruses-Agents of Change in the Oceans. Front. Young Minds 9:569372. doi: 10.3389/frym.2021.569372

CONFLICT OF INTEREST: The authors declare that the research was conducted in the absence of any commercial or financial relationships that could be construed as a potential conflict of interest.

COPYRIGHT () 2021 Avrani and Sher. This is an open-access article distributed under the terms of the Creative Commons Attribution License (CC BY). The use, distribution or reproduction in other forums is permitted, provided the original author(s) and the copyright owner(s) are credited and that the original publication in this journal is cited, in accordance with accepted academic practice. No use, distribution or reproduction is permitted which does not comply with these terms.

\section{YOUNG REVIEWER}

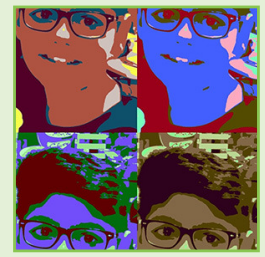

\section{SHASHIPREETHAM, AGE: 14}

Hello, my name is Shashi, I am 14 years old and I go to Penglais School. I enjoy playing football and basketball. My favorite subjects are Maths and computers. I am currently studying year 9. I am a four times Guinness World Records holder in a game called Rocket League and my name is in 2018 Guinness World Record Gamers Edition. 

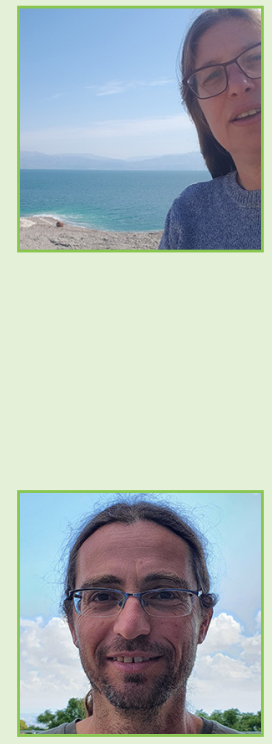

\section{AUTHORS}

\section{SARIT AVRANI}

I am a lecturer at the Department of Evolutionary and Environmental Biology and the Institute of Evolution at the University of Haifa in Israel. In my lab, we study virus-host interactions in aquatic environments. We focus on the influence these interactions have on the ecology and evolution of both viruses and hosts. I think that viruses are very exciting due to their ability to affect their hosts and the environment in so many ways. Moreover, their small size is a benefit in experimental design. In my spare time, I love meeting my friends and spending time with my family. *savrani@univ.haifa.ac.il.

\section{DANIEL SHER}

I am a senior lecturer at the Department of Marine Biology, part of the Leon $\mathrm{H}$. Charney School of Marine Sciences at the University of Haifa in Israel. In my lab, we study how microorganisms interact in the oceans and try to understand the chemical "languages" they use to communicate. The best part of doing research is sharing the excitement of science with students and colleagues. In my spare time, I love to hike, dive, take photographs, cook, and spend time with my family. *dsher@univ.haifa.ac.il. 